\title{
Thermogravimetric and Magnetic Properties of $\mathrm{Ni}_{1-\mathrm{x}} \mathrm{Zn}_{\mathrm{x}} \mathrm{Fe}_{2} \mathrm{O}_{4}$ Nanoparticles Synthesized by Coprecipitation
}

\author{
Kandasamy Velmurugan ${ }^{a, *}$, Vellaiyappan Sangli Karuppanan Venkatachalapathy ${ }^{\mathrm{b}}$ \\ Sechassalom Sendhilnathan ${ }^{\mathrm{c}}$ \\ ${ }^{a}$ Sri Chandrasekharendra Saraswathi Viswa Mahavidyalaya \\ University, Kanchipuram - 631561, India \\ ${ }^{\mathrm{b}}$ Sri Manakula Vinayagar Engineering College, Pondicherry - 605 107, India \\ ${ }^{c}$ Department of Physics, Anna University Tiruchirappalli - Pattukkottai Campus, \\ Thanjavur Dist. - 614 701, Tamil Nadu, India
}

Received: October 19, 2009; Revised: November 11, 2009

\begin{abstract}
$\mathrm{Ni}_{1-\mathrm{x}} \mathrm{Zn}_{\mathrm{x}} \mathrm{Fe}_{2} \mathrm{O}_{4}$ ( $\mathrm{x}=0$ to 1$)$ nanoparticles of size less than $9 \mathrm{~nm}$ were prepared by a chemical coprecipitation method which could be used for ferrofluid preparation. XRD, VSM and DTA-TG (STA) were used to study the effect of variation in $\mathrm{Zn}$ substitution and its influence on particle size, magnetic properties such as $\mathrm{M}_{\mathrm{S}}, \mathrm{H}_{\mathrm{C}}$ and Curie temperature, as well as on the water content. ICP was used to estimate $\mathrm{Ni}, \mathrm{Zn}$ and Fe concentrations. The average crystallite size $\left(\mathrm{D}_{\text {aveXR }}\right)$ of the particles was found to decrease from 8.95 to $6.92 \mathrm{~nm}$ with increasing zinc substitution. The lattice constant $\left(\mathrm{a}_{\mathrm{o}}\right)$ increased with increasing zinc substitution. The specific saturation magnetization $\left(\mathrm{M}_{\mathrm{S}}\right)$ of the particles was measured at room temperature. Magnetic parameters such as $\mathrm{M}_{\mathrm{s}}, \mathrm{H}_{\mathrm{c},}$ and $\mathrm{M}_{\mathrm{r}}$ were found to decrease with increasing zinc substitution. Estimation of the water content, which varies the $\mathrm{Zn}$ concentration, plays a vital role for the correct determination of cation contents. The Curie temperature was found to decrease with increasing zinc substitution.
\end{abstract}

Keywords: coprecipitation, fine particles, nanoferrites, spinel

\section{Introduction}

Magnetic nanoparticles are of great technological importance because of their use in magnetic fluids, information storage systems, medical diagnostics etc. Various preparation techniques have been used for the synthesis of fine particles of ferrites, which exhibit novel properties when compared to their properties in the bulk. Nonconventional methods such as coprecipitation, thermal decomposition, sol-gel and hydrothermal methods have been widely used. Ultrafine ferrite particles can be prepared by the chemical coprecipitation method. Auzans et al..$^{1,2}$ have studied the preparation and properties of $\mathrm{Mn}-\mathrm{Zn}$ ferrite nanoparticles, which were used in ionic and surfacted ferrofluids with different degrees of $\mathrm{Zn}$ substitution prepared by the coprecipitation method. Chandana Rath et al. ${ }^{3}$ have reported the dependence on cation distribution of crystallite size, lattice parameter and magnetic properties in nanosized $\mathrm{Mn}-\mathrm{Zn}$ ferrite for different degrees of $\mathrm{Zn}$ substitution prepared by hydrothermal precipitation method. The use of Mn-Zn ferrite for the preparation of temperature sensitive magnetic fluids by the coprecipitation method has already been studied ${ }^{4-6} . \mathrm{Ni}_{0.2} \mathrm{Zn}_{0.8} \mathrm{Fe}_{2} \mathrm{O}_{4}$ fine particles have been prepared by chemical coprecipitation method followed by sintering ${ }^{7}$. Control of crystallite size in the nanometer range by variation of synthesis condition is always a difficult task and becomes mandatory in the case of ferrofluid preparation using the coprecipitation method. In order to prepare ferrofluids having such fine particles, a specific size restriction is imposed considering the stability criteria. $\mathrm{Ni}_{1-\mathrm{x}} \mathrm{Zn}_{\mathrm{x}} \mathrm{Fe}_{2} \mathrm{O}_{4}$ substituted ferrites with $\mathrm{x}$ varying from 0 to 1.0 prepared by the coprecipitation method have not yet been fully studied like Mn-Zn substituted ferrites. In this paper we report preparation of $\mathrm{Me}_{1-\mathrm{x}} \mathrm{Zn}_{\mathrm{x}} \mathrm{Fe}_{2} \mathrm{O}_{4}$ fine particles, where $\mathrm{Me}=\mathrm{Ni}^{2+}$ with $\mathrm{x}$ varying from 0 to 1.0 with crystallite size less than $13 \mathrm{~nm}$ by the chemical coprecipitation method and the consequent change in magnetic properties, thermomagnetic coefficient, lattice parameter, particle size and associated water content due to zinc substitution.

\section{Synthesis and Characterization of $\mathrm{Ni}_{1-\mathrm{x}} \mathrm{Zn}_{\mathrm{x}} \mathrm{Fe}_{2} \mathrm{O}_{4}$ Nanoparticles}

The magnetization of substituted ferrite nanoparticles synthesized by coprecipitation depends mostly on parameters such as reaction temperature, $\mathrm{pH}$ of the suspension, initial molar concentration etc. ${ }^{4}$. Ultrafine particles of $\mathrm{Ni}_{1-\mathrm{x}} \mathrm{Zn}_{\mathrm{x}} \mathrm{Fe}_{2} \mathrm{O}_{4}$ with $\mathrm{x}$ varying from 0 to 1.0 were prepared by coprecipitating aqueous solutions of $\mathrm{NiCl}_{2}, \mathrm{ZnCl}_{2}$ and $\mathrm{FeCl}_{3}$ mixtures in an alkaline medium. The mixed solution of $\mathrm{NiCl}_{2}$, $\mathrm{ZnCl}_{2}$ and $\mathrm{FeCl}_{3}$ in their respective stoichiometry $(100 \mathrm{~mL}$ of $0.5 \mathrm{M}$ $\mathrm{CoCl}_{2}, 100 \mathrm{~mL}$ of $0.5 \mathrm{M} \mathrm{ZnCl}_{2}$ and $100 \mathrm{~mL}$ of $2 \mathrm{M} \mathrm{FeCl}_{3}$ in the case of $\mathrm{Ni}_{0.5} \mathrm{Zn}_{0.5} \mathrm{Fe}_{2} \mathrm{O}_{4}$ and similarly for the other values of $\mathrm{x}$ ) was prepared and kept at $333 \mathrm{~K}\left(60^{\circ} \mathrm{C}\right)$. This mixture was added to a boiling solution of $\mathrm{NaOH}(0.63 \mathrm{M}$ dissolved in $1200 \mathrm{~mL}$ of distilled water) within $10 \mathrm{~s}$ under constant stirring. Nanoferrites are formed by conversion of metal salts into hydroxides, which take place immediately, followed by transformation of hydroxides into ferrites. The solutions were maintained at $358 \mathrm{~K}\left(85^{\circ} \mathrm{C}\right)$ for $1 \mathrm{hr}$. This time was sufficient for the transformation of hydroxides into spinel ferrite (dehydration and atomic rearrangement involved in the conversion of intermediate hydroxide phase into ferrite $)^{4}$. A sufficient amount of fine particles was collected at this stage using magnetic separation. These particles were washed several times with distilled water followed by acetone and dried at room temperature. 
The X-ray diffraction (XRD) patterns of the samples were recorded on a Philips ${ }^{\circledR}$ PANALYTICAL X' PERT PRO X-ray powder diffractometer using $\mathrm{Cu} \mathrm{K}_{\propto}(\lambda=1.54060 \AA)$ radiation. Slow scans of the selected diffraction peaks were carried out in the step mode (step size $0.05^{\circ}$, measurement time $5 \mathrm{~s}$, measurement temperature $323 \mathrm{~K}\left(25^{\circ} \mathrm{C}\right)$, standard: Si powder). The crystallite size of the nanocrystalline samples was measured from the X-ray line broadening using the Debye- Scherrer formula after accounting for instrumental broadening,

$$
\mathrm{D}_{\mathrm{XRD}}=\frac{0.89 \lambda}{\beta \cos \theta}
$$

where $\mathrm{D}_{\mathrm{XRD}}$ is the crystallite size in $\mathrm{nm}, \lambda$ is the $\mathrm{X}$-ray wavelength in $\AA, \beta$ is the line broadening at half the maximum intensity (FWHM) in radians and $\theta$ is the Bragg angle ${ }^{8}$. The lattice constant $\left(\mathrm{a}_{\mathrm{o}}\right.$ ) was determined for various values of zinc content. Ni-Zn ferrite has a spinel structure ${ }^{9}$. Room temperature magnetic measurements with a maximum magnetic field of $1194.15 \mathrm{kA} / \mathrm{m}$ were carried out using a Lakeshore vibrating sample magnetometer (VSM) (model 7404) and parameters like specific saturation magnetization $\left(\mathrm{M}_{\mathrm{s}}\right)$, coercive force $\left(\mathrm{H}_{\mathrm{c}}\right)$ and remanence $\left(\mathrm{M}_{\mathrm{r}}\right)$ were evaluated. The pulse field technique was used for measuring the temperature dependent magnetization of the powder samples $\mathrm{Ni}_{1-\mathrm{x}} \mathrm{Zn}_{\mathrm{x}} \mathrm{Fe}_{2} \mathrm{O}_{4}(\mathrm{x}=0$ to 0.7$)$ with a magnetic field of $80 \mathrm{kA} / \mathrm{m}$. Simultaneous differential thermal analysis and thermogravimetry (DTA-TG) were carried out on the dried precipitate by using a thermal analyzer (NETZSCH STA 409). Samples were heated from room temperature to $1273 \mathrm{~K}$ at a heating rate of $5{ }^{\circ} \mathrm{C} / \mathrm{min}$. The associated water content was estimated by $\mathrm{TG}$ analysis by monitoring the weight of the sample when heated to a maximum of $1273 \mathrm{~K}$ (rate $5{ }^{\circ} \mathrm{C} / \mathrm{min}$.) in a nitrogen atmosphere (NETZSCH STA 409). The water content was estimated from the weight difference measured from room temperature to $1273 \mathrm{~K}$. Estimation of $\mathrm{Ni}^{2+}$, $\mathrm{Mn}^{2+}$ and $\mathrm{Zn}^{2+}$ in the final product was carried out using ICP Analyst 5.2 Ultima 2 (JY Jobin Yvon Horiba). The particles were dissolved using concentrated $\mathrm{HCl}$ and carefully diluted so that the dilution was well within the linear limit depending upon the sensitivity for the estimation of the respective cation ${ }^{10}$. FTIR spectra were recorded for the dried samples of $\mathrm{Ni}_{1-\mathrm{x}} \mathrm{Zn}_{\mathrm{x}} \mathrm{Fe}_{2} \mathrm{O}_{4}$ with $\mathrm{x}$ varying from 0 to 1.0 with an ABB BOMEM 104 FTIR (range 400-4000 $\mathrm{cm}^{-1}$ ) spectrometer. The dried samples were mixed with $\mathrm{KBr}$ and spectra were measured according to transmittance method. The spectra were resolved with a resolution of $4 \mathrm{~cm}^{-1}$.

\section{Result and Discussion}

Generally, XRD can be used to characterize the crystallinity of nanoparticles, and it gives average diameters of all the nanoparticles. The precipitated fine particles were characterized by XRD for structural determination and estimation of crystallite size. XRD patterns were analyzed and indexed using powder X software ${ }^{11}$. All experimental peaks were matched with the theoretically generated one and indexed. The lattice constant $\left(\mathrm{a}_{\mathrm{o}}\right)$ was computed using the 'd' value and with their respective ( $\mathrm{h} \mathrm{k}$ l) parameters. Analysis of the diffraction pattern confirms the formation of cubic spinel structure for all the samples. The strongest reflection comes from the (311) plane, which denotes the spinel phase. All the compositions had a spinel structure. The peaks indexed to (220), (311), (400), (422), (511) and (440) planes of a cubic unit cell, correspond to cubic spinel structure. The calculated lattice constant $\left(\mathrm{a}_{\mathrm{o}}\right)$, identified the samples to be cubic spinel and was refined using Powder X. The XRD pattern for $\mathrm{Ni}_{1-\mathrm{x}} \mathrm{Zn}_{\mathrm{x}} \mathrm{Fe}_{2} \mathrm{O}_{4}$ with $\mathrm{x}=0,0.2,0.4,0.6,0.8$ and 1 is shown Figure 1. The broad XRD lines indicate that the particles are in the nanosize range. The peaks of (220), (311), (400), (422), (511) and (440) were deconvoluted to Lorentzian curves, using Peak Fit software for the determination of FWHM value of the indexed peaks ${ }^{12}$. The lattice constant was found to increase from 8.212 to $8.462 \AA$ with increasing zinc concentration. The lattice constant $\left(a_{0}\right)$ increased with increasing $\mathrm{Zn}$ content, which suggested the formation of a compositionally homogeneous solid solution and was found to be within the range of the lattice constants of $\mathrm{ZnFe}_{2} \mathrm{O}_{4}$ and $\mathrm{NiFe}_{2} \mathrm{O}_{4}$. This increase could be also attributed to the substitution of the large sized $\mathrm{Zn}$ cation for the small sized $\mathrm{Ni}$ cation. The lattice constant obtained for $\mathrm{NiFe}_{2} \mathrm{O}_{4}$ $(8.384 \AA)$ is close to that of bulk $\mathrm{NiFe}_{2} \mathrm{O}_{4}(8.395 \AA)^{[13]}$. The lattice constant for $\mathrm{Ni}-\mathrm{Zn}$ ferrites reported by R.Anantharaman et al. ${ }^{14}$ is very close to our values. Figure 2 shows that the lattice constant increases with increasing zinc concentration. The crystallite size $\left(\mathrm{D}_{\mathrm{XRD}}\right)$ was estimated by the Debye -Scherrer formula ${ }^{11}$ using the full width at half maximum values of the indexed peaks. The average crystallite size $\left(\mathrm{D}_{\text {aveXR }}\right)$ decreases from 8.95 to $6.92 \mathrm{~nm}$ when the partial substitution of zinc increases ( $x=0$ to $x=1.0)$. This value is close to the crystallite size reported by A. Kale et al. ${ }^{9}$. Though all the samples were prepared under identical conditions, the crystallite size was not the same for all $\mathrm{Zn}$ concentrations. This was probably due to the preparation conditions, which gave rise to different rates of ferrite formation for different concentrations of zinc, favoring the variation of crystallite size. The variation of average crystallite size with zinc concentration is given in Figure 3. Ferrofluids can be conveniently prepared with particles in this size range.

In the cubic system of ferrimagnetic spinels, magnetic order is mainly due to a superexchange interaction mechanism between metal

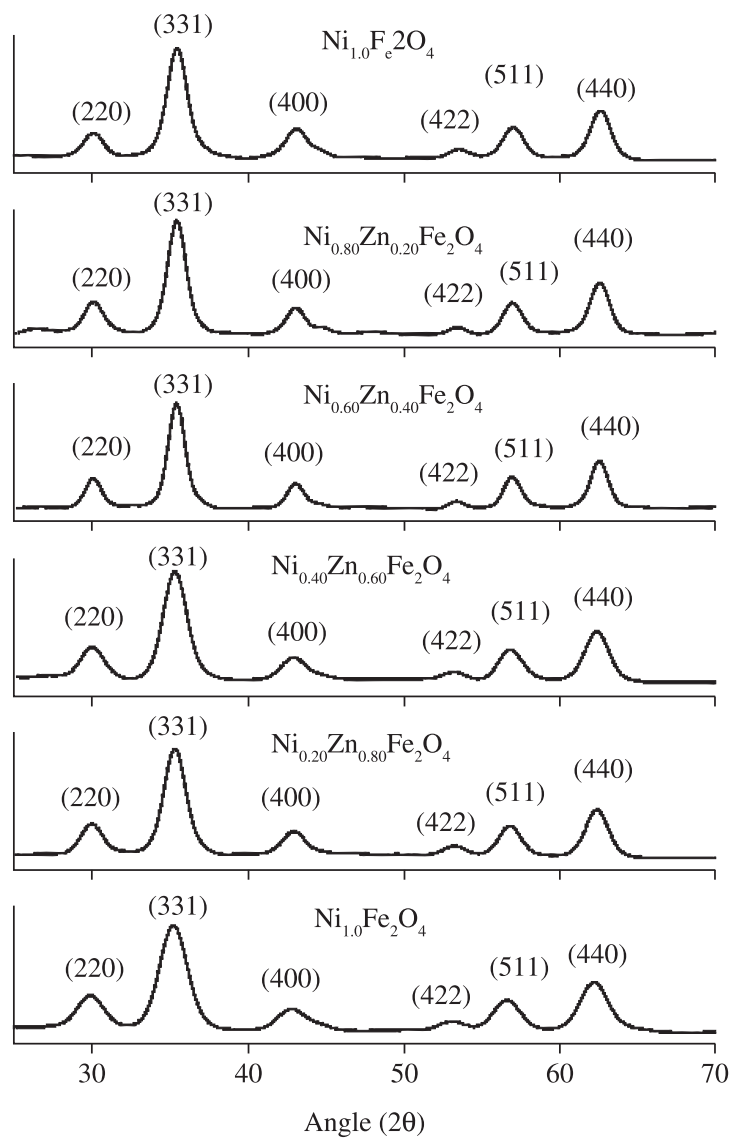

Figure 1. Indexed $\mathrm{X}$-ray diffraction pattern for $\mathrm{Ni}_{1-\mathrm{x}} \mathrm{Zn}_{\mathrm{x}} \mathrm{Fe}_{2} \mathrm{O}_{4}$ with $\mathrm{x}=0,0.2$, $0.4,0.6,0.8$ and 1.0 . 


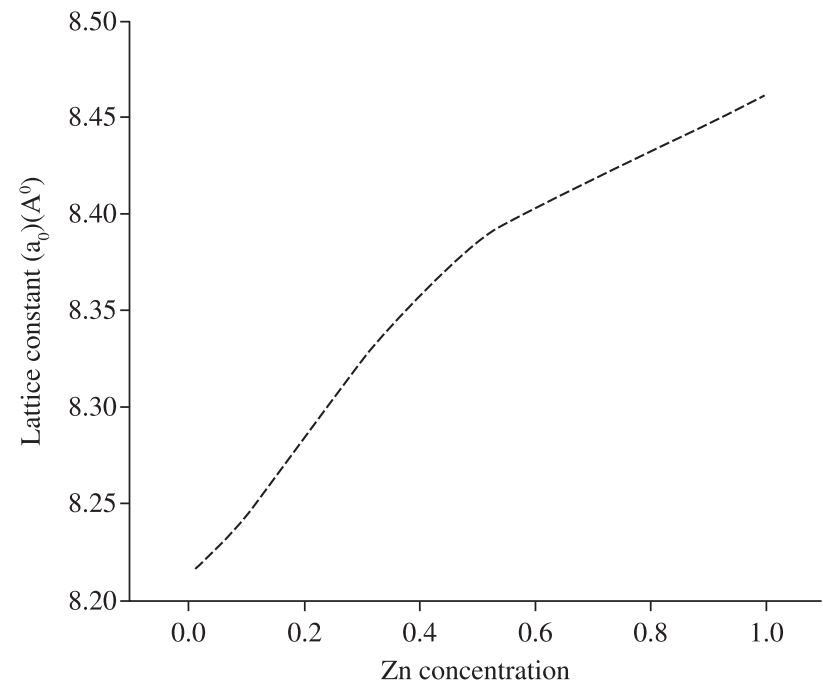

Figure 2. Variation of Lattice constant $\left(\mathrm{a}_{0}\right)(\AA)$ with $\mathrm{Zn}$ concentration for $\mathrm{Ni}_{1-\mathrm{x}} \mathrm{Zn}_{\mathrm{x}} \mathrm{Fe}_{2} \mathrm{O}_{4}$ with $\mathrm{x}$ varying from 0 to 1.0 .

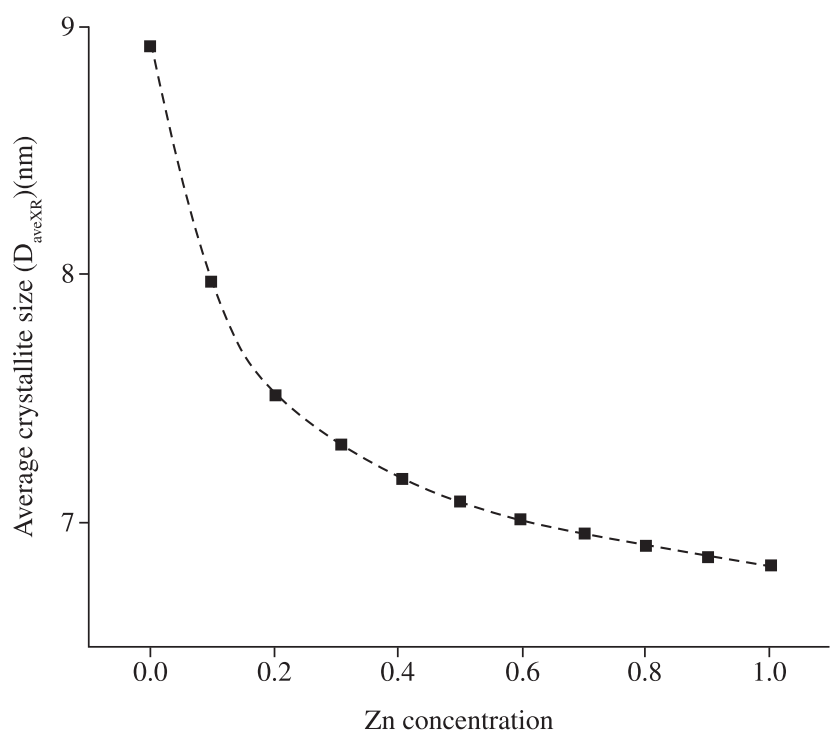

Figure. 3. Variation of the average crystallize size with $\mathrm{Zn}$ concentration for $\mathrm{Ni}_{1-\mathrm{x}} \mathrm{Zn}_{\mathrm{x}} \mathrm{Fe}_{2} \mathrm{O}_{4}$ with $\mathrm{x}$ varying from 0 to 1.0 .

ions in the A and B sublattices. Substitution of nonmagnetic ion such as $\mathrm{Zn}$, which has a preferential A site occupancy, results in reduction of the exchange interaction between A and B sites. Hence, by varying the degree of zinc substitution, it is possible to vary the magnetic properties of the fine particles. Figure 4 shows the room temperature hysteresis loop of the powder samples for various zinc substitutions. From Figure 4 can be seen that the variation pattern of specific saturation magnetization $\left(\mathrm{M}_{\mathrm{s}}\right)$ as a function of $\mathrm{Zn}$ content shows an increase for small substitutions, reaches a maximum value of $46.55 \mathrm{~A} \cdot \mathrm{m}^{2} / \mathrm{kg}$ at $1194.15 \mathrm{kA} / \mathrm{m}$ for $\mathrm{x}=0.1$ and then decreases. The changes in the specific saturation magnetization with the degree of zinc substitution are given in Figure 5. It is clear from Figure 4 that the particles do not show any saturation for $x=0.9$ and 1.0 . even at $1194.15 \mathrm{kA} / \mathrm{m}$ and show an almost linear behavior. Figures 6 and 7 show the variation of remanence $\left(\mathrm{M}_{\mathrm{r}}\right)$ and coercivity $\left(\mathrm{H}_{\mathrm{c}}\right)$, which decrease with increasing zinc substitution. The changes in magnetic properties such as $\mathrm{M}_{\mathrm{s}}, \mathrm{H}_{\mathrm{c}}$ and $\mathrm{M}_{\mathrm{r}}$ are due to the influence of cationic stoichiometry and occupancy of the specific sites. In addition, formation of a dead layer on the surface,

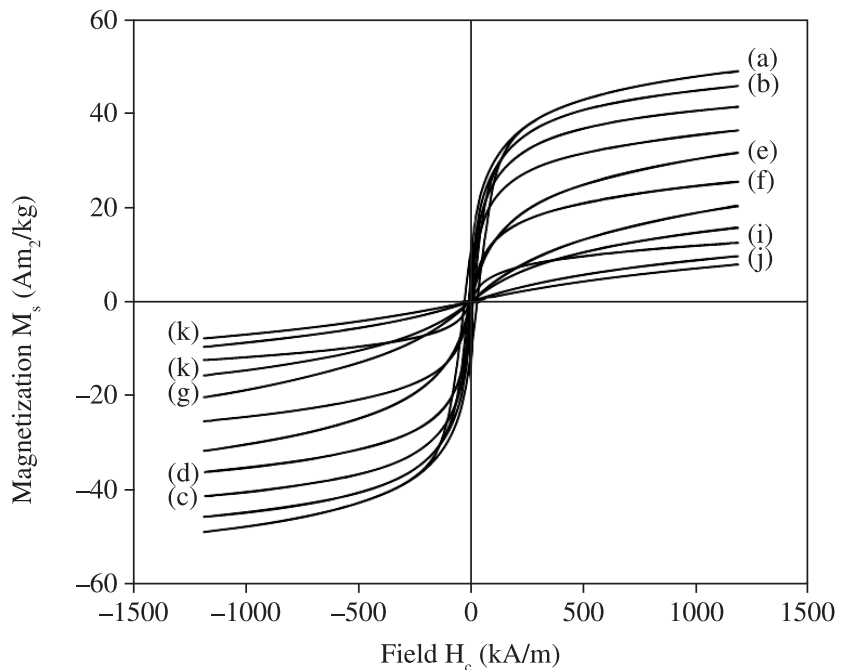

Figure 4. Room temperature magnetization curve of (a) $\mathrm{Ni}_{10} \mathrm{Fe}_{2} \mathrm{O}_{4}$, (b) $\mathrm{Ni}_{0.90} \mathrm{Zn}_{0.10} \mathrm{Fe}_{2} \mathrm{O}_{4}$ (c) $\mathrm{Ni}_{0.80} \mathrm{Zn}_{0.20} \mathrm{Fe}_{2} \mathrm{O}_{4}$, (d) $\mathrm{Ni}_{0.70} \mathrm{Zn}_{0.30} \mathrm{Fe}_{2} \mathrm{O}_{4}$, (e) $\mathrm{Ni}_{0.60} \mathrm{Zn}_{0.40} \mathrm{Fe}_{2} \mathrm{O}_{4}$, (f) $\mathrm{i}_{0.50} \mathrm{Zn}_{0.50} \mathrm{Fe}_{2} \mathrm{O}_{4},(\mathrm{~g}) \mathrm{Ni}_{0.40} \mathrm{Zn}_{0.60} \mathrm{Fe}_{2} \mathrm{O}_{4}$, (h) $\mathrm{Ni}_{0.30} \mathrm{Zn}_{0.70} \mathrm{Fe}_{2} \mathrm{O}_{4}$, (i) $\mathrm{Ni}_{0.20} \mathrm{Zn}_{0.80} \mathrm{Fe}_{2} \mathrm{O}_{4}$, (j) $\mathrm{Ni}_{0.10} \mathrm{Zn}_{0.90} \mathrm{Fe}_{2} \mathrm{O}_{4}$ and (k) $\mathrm{Zn}_{1.0} \mathrm{Fe}_{2} \mathrm{O}_{4}$

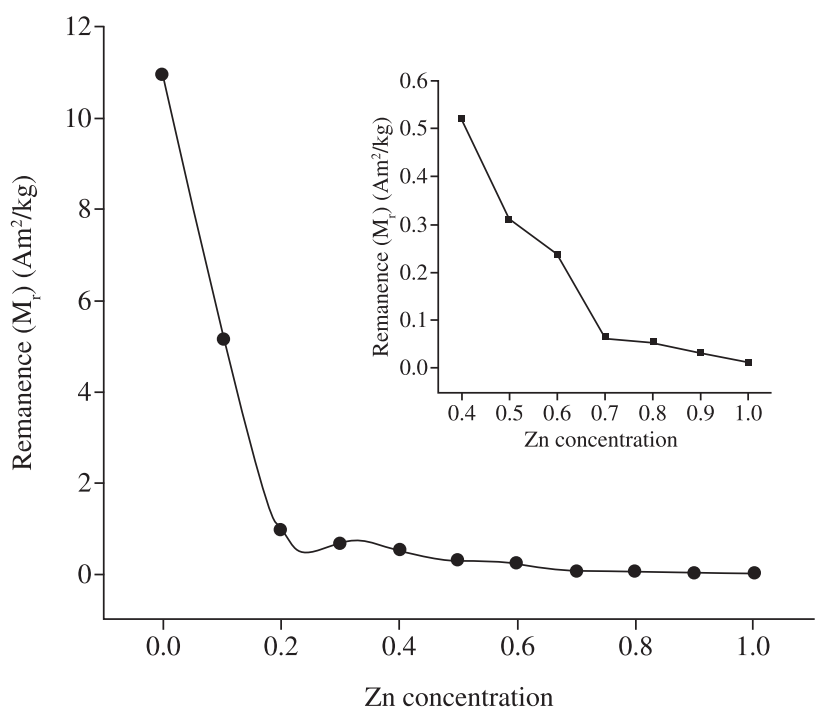

Figure 5. Variation of specific saturation magnetization with $\mathrm{Zn}$ concentration for $\mathrm{Ni}_{1-\mathrm{x}} \mathrm{Zn}_{\mathrm{x}} \mathrm{Fe}_{2} \mathrm{O}_{4}$ with $\mathrm{x}$ varying from 0 to 1.0.

the existence of random canting of particle surface spins ${ }^{12,15}$, nonsaturation effects due to a random distribution of particle sizes, deviation from the normal cation distribution, presence of adsorbed water etc., ${ }^{1}$ might be the cause for the changes in the magnetic properties of the nanoparticles. Reaction temperature of $358 \mathrm{~K}\left(85^{\circ} \mathrm{C}\right)$ and $12.0 \mathrm{pH}$ were used to synthesize $\mathrm{Ni}_{0.9} \mathrm{Zn}_{0.1} \mathrm{Fe}_{2} \mathrm{O}_{4}$ fine particles (10.85 nm in size) having the highest specific saturation magnetization of $46.55 \mathrm{Am}^{2} / \mathrm{kg}$. The deviation of cation distribution in nanoparticles from the bulk, influences the temperature dependence of magnetization. The hysteresis curve (Figure 4) recorded at room temperature shows very low remanence, coercivity for large zinc concentrations which proves that the particles are superparamagnetic at room temperature.

The variation of temperature dependent magnetization measured at $80 \mathrm{kA} / \mathrm{m}$ for $\mathrm{Ni}_{1-\mathrm{x}} \mathrm{Zn}_{\mathrm{x}} \mathrm{Fe}_{2} \mathrm{O}_{4}$ with $\mathrm{x}$ varying from 0 to 0.7 is shown in Figure 8. This is due to the substitution of $\mathrm{Ni}^{2+}$ by a nonmagnetic 


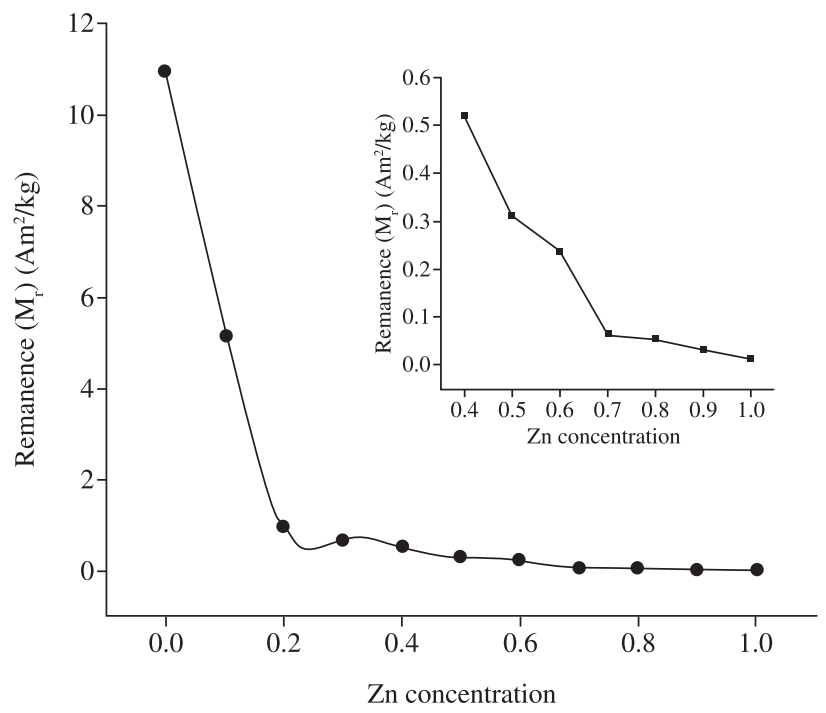

Figure 6. Variation of remanence with $\mathrm{Zn}$ concentration for $\mathrm{Ni}_{4-\mathrm{z}} \mathrm{Zn}_{\mathrm{x}} \mathrm{Fe}_{2} \mathrm{O}_{4}$ with $\mathrm{x}$ varying from 0 to 1.0 (Inset: Variation of remanence with $\mathrm{Zn}$ concentration for $\mathrm{Ni}_{1-x} \mathrm{Zn}_{x} \mathrm{Fe}_{2} \mathrm{O}_{4}$ with $\mathrm{x}$ varying from 0.4 to 1.0.).

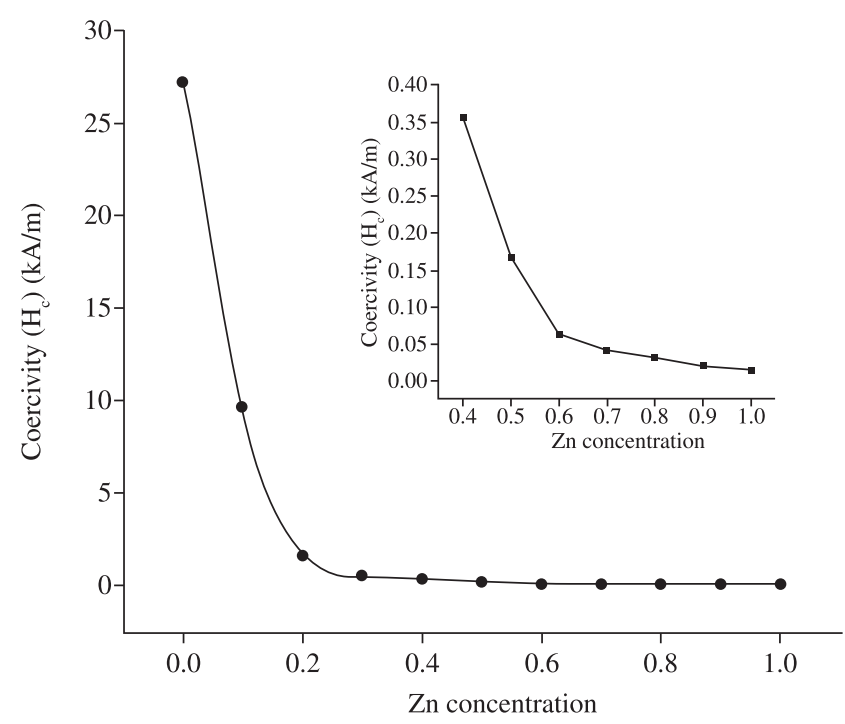

Figure 7. Variation of coercivity with $\mathrm{Zn}$ concentration for $\mathrm{Ni}_{1-x} \mathrm{Zn}_{\mathrm{x}} \mathrm{Fe}_{2} \mathrm{O}_{4}$ with $\mathrm{x}$ varying from 0 to 1.0 (Inset: Variation of coercivity with $\mathrm{Zn}$ concentration for $\mathrm{Ni}_{1-\mathrm{x}} \mathrm{Zn}_{\mathrm{x}} \mathrm{Fe} 2 \mathrm{O} 4$ with $\mathrm{x}$ varying from 0.4 to 1.0.)

ion $\left(\mathrm{Zn}^{2+}\right)$ in the A site ${ }^{6}$. Since the Curie temperature for samples with $x>0.7$ could not be measured because of the low magnetic force when the particles were dispersed in a carrier liquid, particles with $x>0.7$ were not considered. The practical applications of ferrofluid are decided considering the stability of the fluid and the vapor pressure of the carrier liquid at the operating temperature ${ }^{16}$. The percentage of zinc affects the associated water content. The water content varies from 14.78 to $22.52 \%$ in the case Ni-Zn ferrite (Figure 9). The loss of water by the sample is found maximum around 300 to $700 \mathrm{~K}$. This suggests the presence of water molecules chemically adsorbed to the magnetic particle surface (associated water content). From 700 to $1273 \mathrm{~K}$ the loss of water is small. The formation of ferrites was in accordance with the initial stoichiometry. The initial and final (estimated) cation

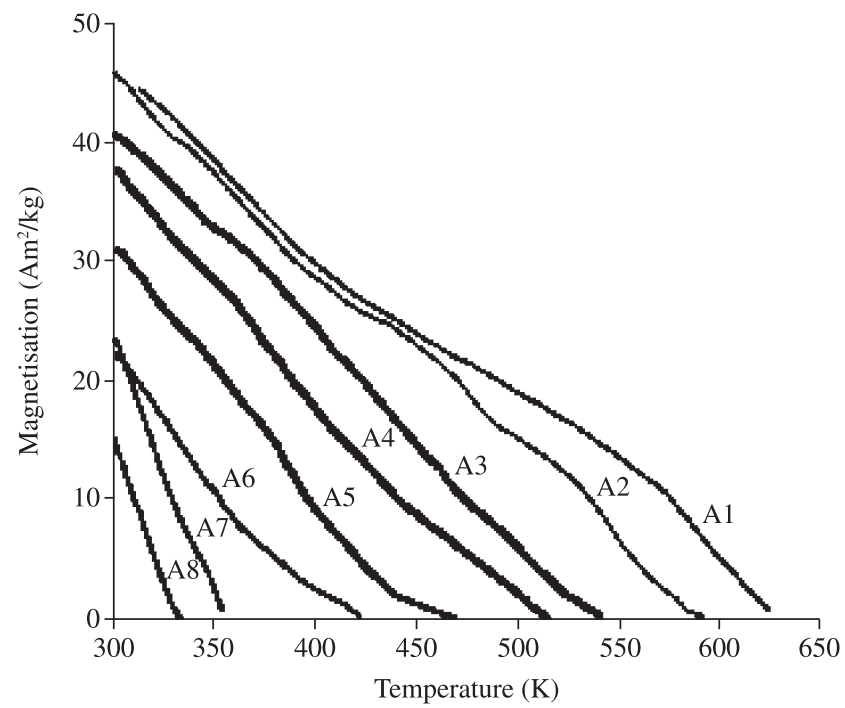

Figure 8. Temperature dependent magnetization measured at $80 \mathrm{kA} / \mathrm{m}$ for (A1) $\mathrm{Ni}_{1.0} \mathrm{Fe}_{2} \mathrm{O}_{4}$, (A2) $\mathrm{Ni}_{0.90} \mathrm{Zn}_{0.10} \mathrm{Fe}_{2} \mathrm{O}_{4}$, (A3) $\mathrm{Ni}_{0.80} \mathrm{Zn}_{0.20} \mathrm{Fe}_{2} \mathrm{O}_{4}$, (A4) $\mathrm{Ni}_{0.70} \mathrm{Zn}_{0.30} \mathrm{Fe}_{2} \mathrm{O}_{4}$, (A5) $\mathrm{Ni}_{0.60} \mathrm{Zn}_{0.40} \mathrm{Fe}_{2} \mathrm{O}_{4},(\mathrm{~A} 6) \mathrm{Ni}_{0.50} \mathrm{Zn}_{0.50}{ }^{0.80} \mathrm{Fe}_{2} \mathrm{O}_{4}$, (A7) $\mathrm{Ni}_{0.40} \mathrm{Zn}_{0.60} \mathrm{Fe}_{2} \mathrm{O}_{4}$, (A8) $\mathrm{Ni}_{0.30} \mathrm{Zn}_{0.70} \mathrm{Fe}_{2} \mathrm{O}_{4}$.

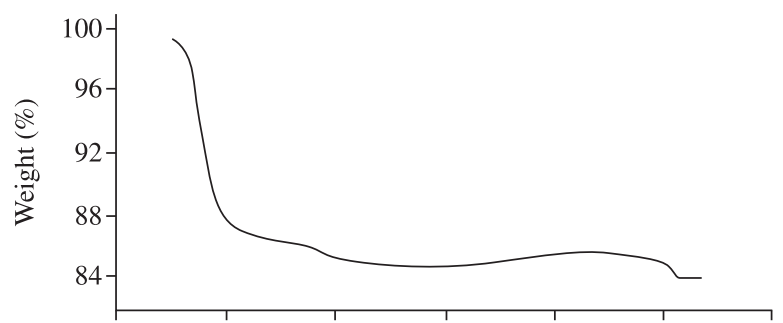

(a)

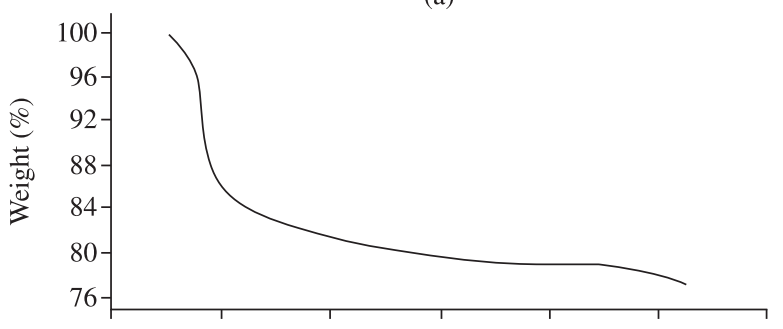

(b)

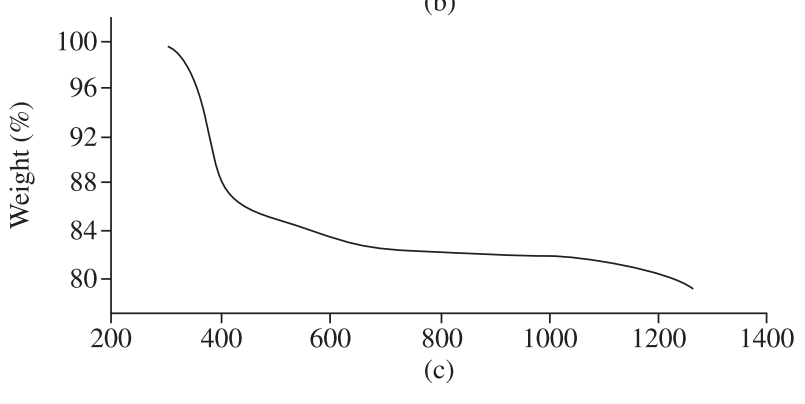

Temperature (K)

Figure 9. Thermo gravimetric analysis for $(\mathrm{A}) \mathrm{Ni}_{1.0} \mathrm{Fe}_{2} \mathrm{O}_{4}(\mathrm{~B}) \mathrm{Ni}_{0.50} \mathrm{Zn}_{0.50} \mathrm{Fe}_{2} \mathrm{O}_{4}$ (C) $\mathrm{Zn}_{1.0} \mathrm{Fe}_{2} \mathrm{O}_{4}$.

concentrations of the prepared samples are shown in Table 1. The ratio $\left(\mathrm{Me}^{2+}\right) /\left(\mathrm{Fe}^{3+}\right)$ initially taken was 0.5 and the ratio obtained for the final product varied from 0.507 to 0.484 in the case of Ni- $\mathrm{Zn}$ ferrite. $\mathrm{Ni}-\mathrm{Zn}$ ferrites did not deviate (within the allowed experimental errors including estimation of water content, dilution etc.) from the initial stoichiometry and matched well with the initial degree of substitution 
Table 1. Initial and the estimated final cation concentrations for $\mathrm{Ni}_{1-\mathrm{x}} \mathrm{Zn}_{\mathrm{x}} \mathrm{Fe}_{2} \mathrm{O}_{4}$ with $\mathrm{x}$ varying from 0 to 1.0.

\begin{tabular}{|c|c|c|c|c|c|c|}
\hline \multicolumn{6}{|c|}{ Cation concentration } & \multirow{3}{*}{$\begin{array}{l}\text { Samples with } \\
\text { estimated cation }\end{array}$} \\
\hline \multicolumn{2}{|c|}{$\mathrm{NiO}^{2+}$} & \multicolumn{2}{|c|}{$\mathrm{Zn}^{2+}$} & \multicolumn{2}{|c|}{$\mathrm{Fe}^{3+}$} & \\
\hline Initial & $\begin{array}{c}\text { Final } \\
\text { (estimated) }\end{array}$ & Initial & $\begin{array}{c}\text { Final } \\
\text { (estimated) }\end{array}$ & Initial & $\begin{array}{c}\text { Final } \\
\text { (estimated) }\end{array}$ & \\
\hline 1.0 & 0.98 & 0 & 0 & 2 & 1.99 & $\mathrm{Ni}_{0.98} \mathrm{Fe}_{1.99} \mathrm{O}_{4}$ \\
\hline 0.9 & 0.89 & 0.1 & 0.10 & 2 & 1.96 & $\mathrm{Ni}_{0.89} \mathrm{Zn}_{0.10} \mathrm{Fe}_{1.96} \mathrm{O}_{4}$ \\
\hline 0.8 & 0.78 & 0.2 & 0.19 & 2 & 1.99 & $\mathrm{Ni}_{0.78} \mathrm{Zn}_{0.19} \mathrm{Fe}_{1.99} \mathrm{O}_{4}$ \\
\hline 0.7 & 0.69 & 0.3 & 0.29 & 2 & 1.97 & $\mathrm{Ni}_{0.69} \mathrm{Zn}_{0.29} \mathrm{Fe}_{1.97} \mathrm{O}_{4}$ \\
\hline 0.6 & 0.58 & 0.4 & 0.38 & 2 & 1.98 & $\mathrm{Ni}_{0.58} \mathrm{Zn}_{0.38} \mathrm{Fe}_{1.98} \mathrm{O}_{4}$ \\
\hline 0.5 & 0.50 & 0.5 & 0.49 & 2 & 1.95 & $\mathrm{Ni}_{0.50} \mathrm{Zn}_{0.49} \mathrm{Fe}_{1.95} \mathrm{O}_{4}$ \\
\hline 0.4 & 0.38 & 0.6 & 0.58 & 2 & 1.98 & $\mathrm{Ni}_{0.38} \mathrm{Zn}_{0.0 .58} \mathrm{Fe}_{1.98} \mathrm{O}_{4}$ \\
\hline 0.3 & 0.28 & 0.7 & 0.70 & 2 & 1.98 & $\mathrm{Ni}_{0.28} \mathrm{Zn}_{0.70} \mathrm{Fe}_{1.98} \mathrm{O}_{4}$ \\
\hline 0.2 & 0.19 & 0.8 & 0.79 & 2 & 1.97 & $\mathrm{Ni}_{0.19} \mathrm{Zn}_{0.79} \mathrm{Fe}_{1.97} \mathrm{O}_{4}$ \\
\hline 0.1 & 0.09 & 0.9 & 0.89 & 2 & 1.98 & $\mathrm{Ni}_{0.09} \mathrm{Zn}_{0.89} \mathrm{Fe}_{1.98} \mathrm{O}_{4}$ \\
\hline 0 & 0 & 1.0 & 0.99 & 2 & 1.99 & $\mathrm{Zn}_{0.99} \mathrm{Fe}_{1.99} \mathrm{O}_{4}$ \\
\hline
\end{tabular}

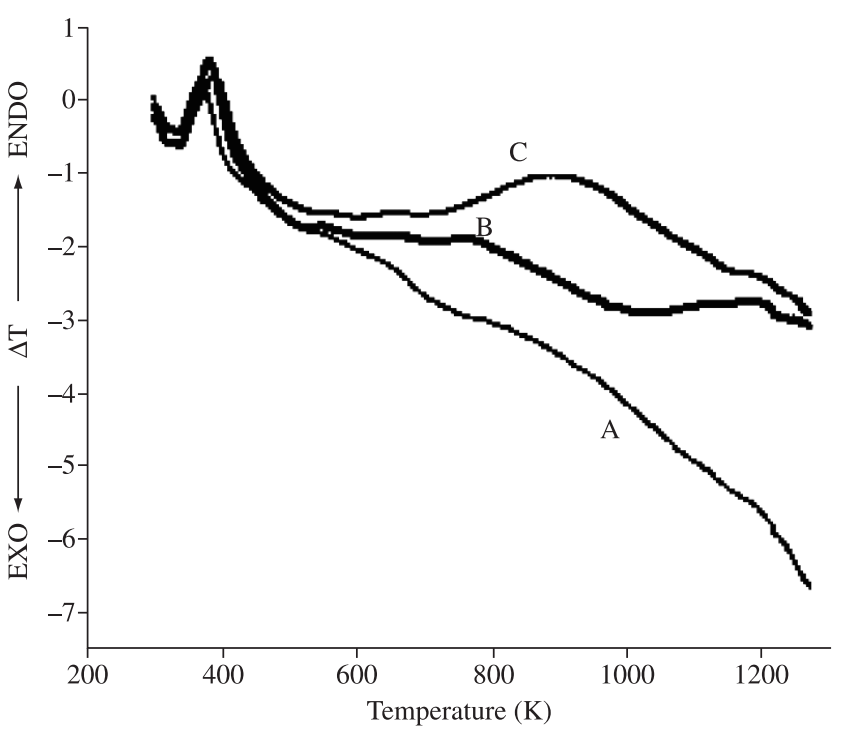

Figure 10. DTA curve for (A) $\mathrm{Ni}_{1.0} \mathrm{Fe}_{2} \mathrm{O}_{4}$ (B) $\mathrm{Ni}_{0.50} \mathrm{Zn}_{0.50} \mathrm{Fe}_{2} \mathrm{O}_{4}$ (C) $\mathrm{Zn}_{1.0} \mathrm{Fe}_{2} \mathrm{O}_{4}$.

when rounded to the first decimal. It is interesting to note that the initial and final $\mathrm{Zn}$ concentrations are almost the same and the preparation conditions completely favor the formation of ferrites allowing us to study the effect of $\mathrm{Zn}$ substitution on the properties of the ferrites. The DTA curves for $\mathrm{Ni}_{1-\mathrm{x}} \mathrm{Zn}_{\mathrm{x}} \mathrm{Fe}_{2} \mathrm{O}_{4}$ with $\mathrm{x}=0,0.5$ and 1 are shown in Figure 10. All DTA curves show an endothermic peak around $350 \mathrm{~K}$, which confirms the presence of water in the $\mathrm{Ni}_{1-\mathrm{x}} \mathrm{Zn}_{\mathrm{x}} \mathrm{Fe}_{2} \mathrm{O}_{4}$ samples. The broad hump at around 800 to $1200 \mathrm{~K}$ may correspond to complete crystallization in the cubic spinel phase (ferrite formation).

The FTIR spectra for $\mathrm{Fe}_{3} \mathrm{O}_{4}$ and for $\mathrm{Ni}_{1-\mathrm{x}} \mathrm{Zn}_{\mathrm{x}} \mathrm{Fe}_{2} \mathrm{O}_{4}$ with $\mathrm{x}=0,0.5$ and 1 are shown in Figure 11. By overlaying the FTIR spectra for $\mathrm{Fe}_{3} \mathrm{O}_{4}$ and for $\mathrm{Ni}_{1-\mathrm{x}} \mathrm{Zn}_{\mathrm{x}} \mathrm{Fe}_{2} \mathrm{O}_{4}$ with $\mathrm{x}=0,0.5$ and 1.0, the spectral similarities are observed. The broad feature between $3441.43-3219.90 \mathrm{~cm}^{-1}$ is due to $\mathrm{O}-\mathrm{H}$ stretch $\left(\mathrm{v}_{1}\right)$, which corresponds to the hydroxyl groups attached by the hydrogen bonds to the iron oxide surface and the water molecules chemically adsorbed to the magnetic particle surface (associated water content $)^{17}$. From these results, it appears that the hydroxyl groups are retained in the samples during preparation of uncoated $\mathrm{Ni}_{1-\mathrm{x}} \mathrm{Zn}_{\mathrm{x}} \mathrm{Fe}_{2} \mathrm{O}_{4}$. Ghose et al.$^{7}$ have reported that some

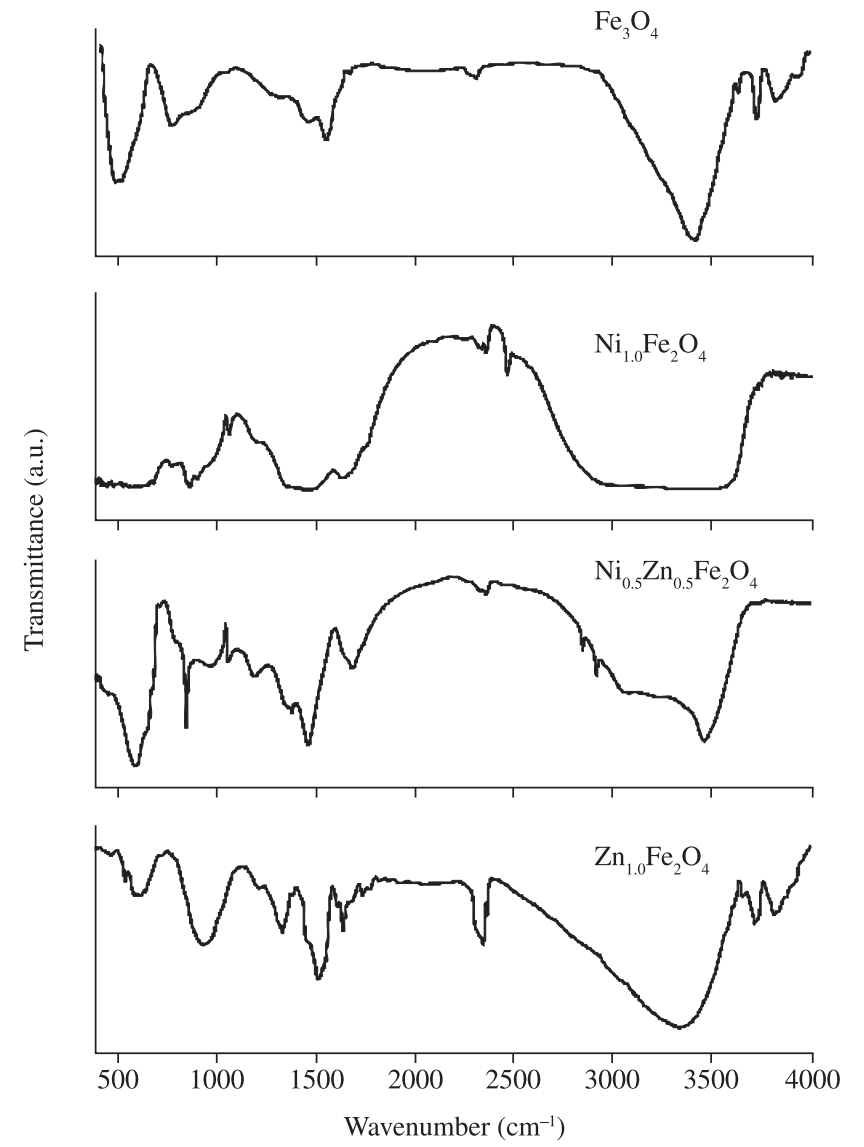

Figure 11. FTIR spectra for $\mathrm{Fe}_{3} \mathrm{O}_{4}$ and for uncoated $\mathrm{Ni}_{1-x} \mathrm{Zn}_{\mathrm{x}} \mathrm{Fe}_{2} \mathrm{O}_{4}$ with $\mathrm{x}=0,0.5$ and 1.0 .

hydroxyl ions are completely removed when the sample is sintered at temperatures $\geq 973 \mathrm{~K}^{[18]}$. The O-H in-plane and out-of-plane bonds appear at $1537.80-1500.31 \mathrm{~cm}^{-1}$ and $960.03-874.235 \mathrm{~cm}^{-1}$, respectively. The spectrum of the uncoated sample $\mathrm{Ni}_{0.90} \mathrm{Zn}_{0.10} \mathrm{Fe}_{2} \mathrm{O}_{4}$ shows a strong band from 635.57 to $573.51 \mathrm{~cm}^{-1}$ due to $\mathrm{Fe}_{3} \mathrm{O}_{4}{ }^{[18]}$. The transmittance waveband from 635.57 to $573.51 \mathrm{~cm}^{-1}$, which corresponds to the metal-oxygen bonds, are considered as the confirmation for the ferrite formation. This is in good agreement with Zins et al. ${ }^{1,19-22}$. 


\section{Conclusion}

The preparation technique of nanoparticles has a definite influence on the control of particle size and magnetic properties. The estimated cations from the product are in agreement with the initial substitution, indicating that the preparation procedure favors the formation of only ferrites. The formation of $\mathrm{Ni}_{1-\mathrm{x}} \mathrm{Zn}_{\mathrm{x}} \mathrm{Fe}_{2} \mathrm{O}_{4}$ was confirmed by the $\mathrm{X}$-ray diffraction. The lattice constant was found to increase with the increase in zinc concentration. The average crystallite size $\left(\mathrm{D}_{\text {aveXR }}\right)$ decreased when the partial substitution of zinc increased ( $x=0$ to1.0). The specific saturation magnetization was found to decrease with the increase in zinc substitution except for $\mathrm{x}=0$. Low coercivity was observed for high $\mathrm{Zn}$ concentrations. The samples prepared by coprecipitation showed superparamagnetic behavior, which was documented by the hysteresis loop, measured at room temperature. The Curie temperature and the temperature at which the maximum value of thermomagnetic coefficient is observed decrease with increasing $\mathrm{Zn}$ concentration. FTIR was used to confirm the formation of $\mathrm{Fe}-\mathrm{O}$ bonds and presence of the associated water in the samples.

\section{References}

1. Auzans E, Zins D, Blums E and Massart R. Synthesis and properties of Mn-Zn ferrite ferrofluids. Jour.nal of Materials Science. 1999; 34(6): $1253-1260$

2. Auzans E, Zins D, Blums E and Massart R. Propertities of Mn-Zn ferrite nanoparticles for aqueous ferrofluids. Magnetohydrodynamics. 1999; 35(1): $78-86$

3. Chandana Rath, Anand S, Das RP, Sahu KK, Kulkarni SD, Date SK and Mishra NC. Dependence on cation distribution of particle size, lattice parameter, and magnetic properties in nanosize $\mathrm{Mn}-\mathrm{Zn}$ ferrite. Journal of Applied Physics. 2002; 91(4): 2211.

4. Jeyadevan B, Chinnasamy CN, Shinoda K and Tohji K. Mn-Zn ferrite with higher magnetization for temperature sensitive magnetic fluid. Journal of Applied Physics. 2003; 93(10): 8450.

5. Kinnary Parekh, Upadhyay RV and Mehta RV. Electron spin resonance study of a temperature sensitive magnetic fluid. Journal of Applied Physics. 2000; 88 (5): 2799.

6. Tripti Upadhyay, Upadhyay RV and Mehta RV. Characterization of a temperature - sensitive magnetic fluid. Physical Review B (Condensed Matter). 1977; 55(9): 5585-5588

7. Dey S and Ghose J. Synthesis, characerization and magnetic studies on nanocrystalline $\mathrm{Co}_{0.2} \mathrm{Zn}_{0.8} \mathrm{Fe}_{2} \mathrm{O}_{4}$. Materials Research Bulletin. 2003; 38(11-12): 1653-1660
8. Cullity BD. Elements of X-ray diffraction. 2 ed. London: Addison Wesley Publishing Company; 1978.

9. Kale A, Gubbala S and Misra RDK. Magnetic behaviour of nanocrystaline nickel ferrite synthesized by the reverse micelle technique. Journal of Magnetism and Magnetic Materials. 2004; 277(3): 350- 358.

10. Jeffery GH, Bassett J, Mendham J and Denney RC. Vogel's Textbook of Quantitative Chemical Analysis. UK: Longman Group; 1989. p. 691.

11. Dong C. PowderX: Windows-95-based program for powder X-ray diffration data processing. Journal of Applied Crystallography. 1999; 32(4): 838-838.

12. Han DH, Wang JP and Lou HL . Crystallite size effect on saturation magnetizaton of fine ferrimagnetic particles. Journal of Magnetism and Magnetic Materials. 1994; 136(1-2): 176-182.

13. Kim Y, Kim D and Lee CS. Synthesis and characterization of $\mathrm{CoFe}_{2} \mathrm{O}_{4}$ magnetic nanoparticles prepared by temperature-controlled coprecipitation method. Physica B. 2003; 337(1-4): 42-51.

14. Anantharaman MR et al. On the magnetic properties of ultra-fine zinc ferrites. Journal of Magnetism and Magnetic Materials. 1998 ; 189(1): 83-88.

15. Kale GM and Asokan T. Electrical properties of Cobolt - zinc ferrites. Applied Physics Letters. 1993; 62(19): 2324.

16. Scholten PC. Some material problems in magnetic fluids. Chemical Engineering Communications. 1988; 67(1): 331-340.

17. Creanga D and Calugaru G. Physical investigations of a ferrofluid based on hydrocarbons. Journal of Magnetism and Magnetic Materials. 2005; 289: $81-83$.

18. Ahn Y, Choi EJ and Kim EH. Superparamagnetic relaxation in cobalt ferrite nanoparticles synthesized from hydroxide carbonate precursors. Reviews on Advanced Materials Science, 2003; 5: 477-480.

19. Ming Ma, Yu Zhang, Wei Yu, Hao-Ying Shen, Hai-qian Zhang, Ning Gu. Preparation and characterization of magnetite nanoparticles coated by amino silane. Colloids and Surfaces A: Physicochemical and Engineering Aspects. 2003; 212(2-3): 219-226.

20. Ahmed SR and Kofinas P. Magnetic properties and morphology of block copolymer-cobalt oxide nanocomposites. Journal of Magnetism and Magnetic Materials. 2005; 288: 219-223.

21. Ishikawa T, Nakazaki H, Yasukawa A, Kandori K and Seto M. Influences of $\mathrm{Co}^{2+}, \mathrm{Cu}^{2+}$ and $\mathrm{Cr}^{3+}$ ions on the formation of magnetite. Corrosion Science. 1999; 41(8): 1665-1680.

22. Wu N, Fu L, Su M, Aslam M, Chun Wong K and Dravid VP. Interaction of Fatty Acid Monolayers with Cobalt Nanoparticles. Nano Letters. 2004; 4(2): 383-386. 